\title{
Adaptiv Neyro-Fuzzy Şəbəkələr Vasitəsilə Aeroşəkillərdən Binaların Seçilməsi
}

\author{
Kamil Ayda-zadə ${ }^{1}$, Cəmaləddin Həsənov ${ }^{2}$ \\ ${ }^{1,2}$ AMEA İdarə Sistemləri İnstitutu, Bak1, Azərbaycan \\ ${ }^{1}$ kamil_aydazade@rambler.ru, ${ }^{2}$ jhasanov@gmail.com
}

\begin{abstract}
Xülasə- Məqalədə aeroşəkillərdən binaların seçilməsi üçün rənglərə görə regionların tapılması üsulu təsvir edilmişdir. Üsulda xətt parçalarının ətrafında yerləşən regionların rəng yaxınlığına görə tapılması və bina olması barədə qərar verilməsi təklif edilir. Rənglərin yaxınlıq meyarı hər bir rong qrupu üçün ayrıca qurulmuş ANFIS şəbəkəsinin qərarına əsasən təyin edilir. Məqalənin yekununda verilmiş məsələ üçün əlamətlər, müxtəlif öyrənmə yanaşmaları və təcrübə nəticələri barədə ətraflı məlumat verilir.
\end{abstract}

Açar sözlor-ANFIS, aeroşəkillor, tanıma, olamətlor

\section{GİRIŞ}

Obyektləri tanımanın xüsusi və geniş sahəsi olan kosmik və aero çəkilişlərdən obyektlərin tanınması uzun müddət aktual problem olmuşdur. Son on il ərzində bu təsvirlərin kommersiya və fərdi istifadə üçün açılması bu sahədə aparılan işlərin daha da sürətlənməsinə gətirib çıxardı. Hal-hazırda bu sahə hidrometrologiya, şəhərsalma, təhlükəsizlik, naviqasiya və fəlakətlərin aşkar edilməsi kimi problemlərin həllinə kömək edir.

Təsvirin növünə (kosmik və ya aeroşəkil) və məsələnin qoyuluşuna görə müxtəlif yanaşma, üsul və alqoritmlər təklif edilmişdir. [1]-də 1984-1998-ci illər ərzində təklif edilmiş üsulların geniş xülasəsi verilmişdir. Bu üsullarda əsasən boz rəngli aeroşəkillərdən sərhədlərin tapılması və keçid təhlilindən istifadə edilərək, binaların tapılması probleminə baxılır. [2] və [3]-də təsvirlərdən inzibati obyektlər və küçələrin tapılması üçün işlənmiş üsullar təsvir edilmişdir. [4-6]-da təqdiqat obyekti kimi seçilən binaların tapılması üçün kölgə təhlili, rəng keçidləri, infraqırmızı səviyyə məlumatının istifadəsi ilə bir çox üsullar təklif edilmişdir.

Məqalədə ənənəvi yanaşmalardan bir qədər fərqli olan, evristik üsul və rəng yaxınlığı üçün xüsusi mülahizə yürütməyə imkan verən sistemin təsviri verilmişdir.

\section{TOKLIFF EDİLӘN YANAŞMA}

\section{A. Sarhadlarin tapılması}

Təsvirdə binaların tapılması üçün müxtəlif yanaşmalardan istifadə edilmişdir. Osas istiqamət təsvirdəki düz xətlər və kəskin rəng keçidlərinin tapılması üzərində qurulmuşdur.

İlk olaraq, təsvirdə olan düz xətlər tapilır. Küyləri aradan qaldırmaq və hamarlama məqsədi ilə əvvəl təsvir boz rəng modelinə keçirilərək, üzərində morfoloji əməliyyatlar aparılır. Alınmış nəticənin üzərində Canny alqorimtinin [7] tətbiqi ilə sərhədlər tapılır və sərhəd xətləri arasında düz xətt parçalarını tapmaq üçün Hough köçürməsindən [8] istifadə edilir. Qeyd edilən prosedur əksər binaları tanıma sistemlərində ilkin mərhələdə tətbiq edilir və əsas fərq tətbiq edilən üsulların istifadə edilmiş parametrləri olur.

Növbəti mərhələ, alınmış düz xətt parçalarına görə binaların tapılması prosesidir. Təklif edilən üsulda aşağıdakı hipotezdən istifadə edilmişdir: əgər təsvirdə hər-hansı düz xətt varsa, böyük ehtimalla o hər-hansı tikilinin (bina və ya qeyri bina) yan tərəfidir. Başqa sözlə, əgər təsvirdə hansısa düz xəttə rast gəlinirsə, demək onun bir və ya hər iki tərəfində insan tərəfindən salınmış obyekt vardır. Bu hipotezin əsasında təbiət obyektlərinin (ağaclar, dağlar, çaylar, dəniz və s.) tərəflərinin istisnaları çıxmaqla, düz xətli olmaması durur.

\section{B. Alqoritmin tosviri}

Təklif edilmiş alqoritmin işləmə qaydası aşağıdakı kimidir:

İlkin emaildan sonra, tapılmış düz xətlərdən yalnız müəyyən ölçü diapazonunda olanlar saxlanılır. Çox kiçik olan xətlər küy, çox uzun xətlər isə yollara aid ola bilər. Bu diapazon təcrübə əsasında tapılmış parametrlə təyin edilir.

Tapılmış parçaların mərkəzindən parçanın hər iki tərəfində, müəyyən məsafədə yerləşən piksellərin rəng məlumatı götürülür. Qeyd edilən rəng nümunələri düz xətt parçasının hər iki tərəfində yerləşən obyektlərin hansı rəngdə ola biləcəyini təyin etmək üçündür və onların parçanın tam yanında deyil aralıda götürülməsi mümkün ola biləcək kölgə zolağını nəzərə almamaq üçündür.

Hər iki nümunə nöqtələri üçün onlara yaxın olan rənglərdən ibarət regionlar tapılır. Tapılmış regionlar təhlil edilir və parametrləri ilə binaya uyğun olan regionlar tanıma noticəsi kimi təklif edilir.

Növbəti hissələrdə düz xətlərin tapılmasından sonra gələn hər bir mərhələnin iş prinsipi göstərilmişdir.

\section{ANFIS ila yaxınlıq meyarının tayini}

Regionu xarakterizə edən rəng nümunəsi təyin edildikdən sonra, regionun tapılması üçün həmin rəngə yaxın rənglərin qruplaşdırılması tələb edilir. Rənglərin yaxınlığını təyin etmək üçün təklif edilən üsulda rəngin qiyməti (Hue) və paylanması (Saturation) kimi parametrləri özündə cəmləşdirən HSV rəng sxeminə keçmək təklif olunur. HSV rəng sxemində Hue rəngin 0-100 arasında qırmızıdan tünd çəhrayıya qədər olan rənglərin kodunu göstərir [9]. Şəkil 1-də iki fərqli bina damının rənglərinin rəngin qiyməti (Hue) spektrlərinə (0-100 arasında) görə paylanması göstərilmişdir. Şəkildən göründüyü kimi, să̆ tərəfdəki bənövşəyi damın rənginin kodlarına baxdıqda, orda 
az da olsa, narıncı və sarı rənglərın iştirakını görmüş olarıq, hansı ki, soldakı binanın Hue spektrində də rast gəlinir.
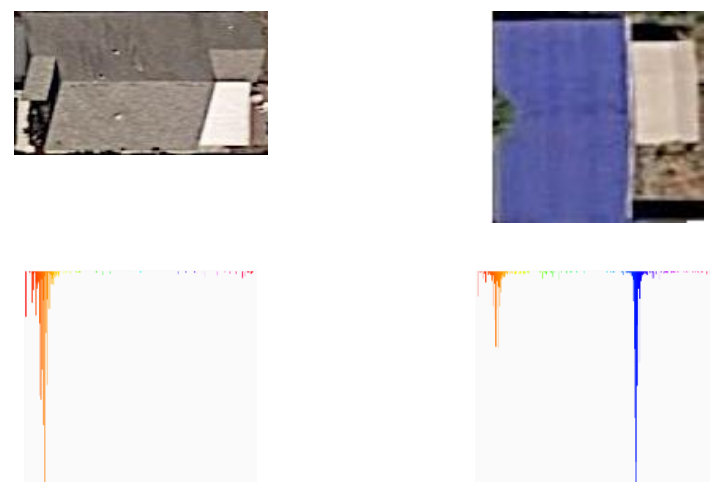

Şəkil 1. Fərqli binaların damının rənglərinin rəng koduna görə paylanması Yuxarıda: orjinal təsvir; aşağıda: rəng qiymətinə (Hue) görə alınmıs histoqram.

Üsulda istifadə edilən yaxınlıq meyarı, region üçün əvvəlcədən verilmiş olan nümunə rəngi və verilmiș rəngin Hue və Saturation parametrlərinin fərqi kimi hesablanır. Burada əsas çətinlik qeyd edilən parametrlərin hər bir rəng üçün müxtəlif diapazonlarda variasiya etməsidir. Məhz bu səbəbdən, rəng üzrə yaxınlığı tapmaq üçün sabit variasiya parametri yaramır. Aparılmış təcrübələr göstərmişdir ki, bu cür yanaşma ilə seqmentasiya aparıldıqda, bəzi binaların damları Hue, digərləri isə Saturation parametrinə görə dəqiq tapılmışdır. Bu vizual olaraq, bəzi hallarda binaların damlarının eyni rəng, lakin fərqli çalarlarda olması, digər hallarda isə eyni çalarda, lakin müəyyən rəng diapazonunda variasiya etməsi ilə (məsələn, günün düşməsi səbəbindən) izah edilə bilər. Bundan əlavə, digər regionlar ya dəqiq tapılmamış, ya da ümumiyyətlə tapılmamışdır. Variasiya sabitlərinin dəyişdirilməsi heç də problemin həllinə kömək etməmişdir.

Qeyd edilən çətinlik eyni regiona aid olan rənglərin ümumi diapazonda deyil, hər bir rəng və rəng parametrlərinə görə fərqli diapazonda dəyişməsindən xəbər verir. Müxtəlif rənglərə görə dəyişən variasiya modeli qurmaq məqsədilə, rənglərin yaxınlıq meyarını təyin edən birinci tərtibli Sugeno tipli Adaptiv Neyro Fuzzy Inference System (ANFIS) şəbəkəsi istifadə edilmişdir (şəkil 2).

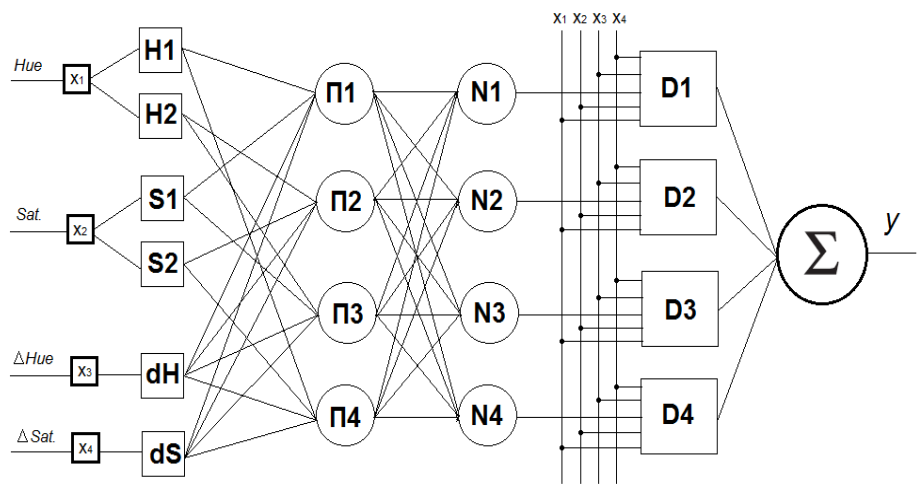

Şəkil 2. Təklif edilən ANFIS strukturu

\section{TOKLIFF EDİLӘN ANFISS STRUKTURU}

Təklif edilən ANFIS şəbəkəsinin girişinə rəngin Hue və Saturation parametrləri ilə bərabər, bu parametrlərin qiymətinin nümunə kimi seçilmiş rəngin uyğun parametrlərinin qiymətindən olan fərqləri verilir. Qeyd edilən şəbəkə girişdə 4 parametri qəbul edərək çıxışda $[0,1]$ diapazonunda rənglərin yaxınlığını qiymətləndirir. Çıxışda alınmış qiymət 1-ə yaxın olduqca rəngin verilmiş nümunəyə daha çox yaxın olması təyin olunur.

ANFIS şəbəkəsinin girişinə veriləcək 4 parametrin hər biri üçün aşağıdakı mənsubiyyət funksiyaları seçilmişdir (cədvəl $1)$ :

CəDVӘL 1. MӘNSUBIYYӘT FUNKSIYALARININ ISŞARӘLӘNMӘSİ

\begin{tabular}{|c|c|c|}
\hline Kod & Təyinat & Mənası \\
\hline H1 & $\begin{array}{l}\text { "Hue" parametrinə uyğun } \\
\text { sigmoid tipli MF }\end{array}$ & $\begin{array}{l}\text { "HUE } \\
\text { DəRӘCOSİ" } \\
\text { (asimmetrik) }\end{array}$ \\
\hline $\mathrm{H} 2$ & $\begin{array}{l}\text { "Hue" parametrinə uyğun Gauss } \\
\text { tipli MF }\end{array}$ & $\begin{array}{l}\text { "HUE } \\
\text { DӘRӘCӘSI"” (simmetrik) }\end{array}$ \\
\hline S1 & $\begin{array}{l}\text { "Saturation" parametrinə uyğun } \\
\text { sigmoid tipli MF }\end{array}$ & $\begin{array}{ll}\text { "SATURATION } & \text { RӘNG } \\
\text { DəRӘCOSI" } \\
\text { (asimmetrik) }\end{array}$ \\
\hline $\mathrm{S} 2$ & $\begin{array}{l}\text { "Saturation" parametrinə uyğun } \\
\text { Gauss tipli MF }\end{array}$ & $\begin{array}{l}\text { "SATURATION } \quad \text { RӘNG } \\
\text { DəRӘCӘSI" } \\
\text { (simmetrik) }\end{array}$ \\
\hline $\mathrm{dH}$ & $\begin{array}{l}\text { "Hue fərqi" parametrinə uyğun } \\
\text { Gauss tipli MF }\end{array}$ & "Hue" qiymatinə "YAXIN" \\
\hline DS & $\begin{array}{l}\text { "Saturation fərqi" } \\
\text { uyğun Gauss tipli MF }\end{array}$ & $\begin{array}{l}\text { "Saturation" } \\
\text { "YAXIN" }\end{array}$ \\
\hline
\end{tabular}

1. Hue vo Saturation parametrlorinin hər biri $[0,1]$ aralığında dəyişir və yuxarıda qeyd edildiyi kimi, rəng diapazonunda müxtəlif rənglər üçün fərqli dəyişmə (variasiya) dərəcəsi olduğu üçün burada mənsubiyyət funksiyası kimi sigmoid və boyu 1 olan Gauss funksiyalarından istifadə edilmişdir. Aktivlik rəng şkalasının əvvəl və ya axırında olduğu halda qanunauyğunluğu sigmoid, mərkəzə yaxın olduğu halda isə Gauss funksiyası müəyyən etməyə kömək edəcəkdir.

2. Hue və Saturation üzro farqlanmə paramterlari $[-1,1]$ aralığında dəyişir və burada sıfra yaxınlıq, verilmiş rəngin nümunəyə yaxınlığını göstərir. $\mathrm{Bu}$ halda mənsubiyyət funksiyasının birmənalı olaraq mərkəz nöqtəsini gücləndirən, mərkəzdən kənar nöqtələrdə isə qiyməti azaldan funksiya tələb olunur. Belə halda bizə Gauss funksiyasından istifadə məqsədəuyğundur.

Qeyd edilən problemi həll etmək üçün, verilmiş mənsubiyyət funksiyaları və şəbəkə parametrləri üçün optimal qiymətləri tapmaq tələb olunur.

\section{NӘTİCӘ}

Təklif edilən üsulun yoxlanılması üçün Matlab® sisteminin uyğun kitabxanalarından istifadə edilmişdir. Müxtəlif aeroşəkillər üzərində aparılmış təcrübə nəticələrinə nəzər yetirdikdə, qeyd edilən alqoritmin əvvəlki üsullardan fəqrli olaraq, mürəkkəb strukturlu binaları daha dəqiq təyin etməsi aydın olur (şəkil 3). Qeyd edilən təcrübələrdə təsvirin yalnız rəng məlumatı istifadə edilmişdir - təsvirdə verilmiş infraqırmızı spektr məlumatı istifadə edilməmişdir. 
Ümumi təcrübə nəticələri alqoritmin təsvirlərdəki binaların mürəkkəblikdən asılı olaraq 45-70\% atrafinda tanımasını göstərir.

Hazırda sistemin emal gücü və dəqiqliyini artırmaq üçün digər kitabxanalardan asılı olmayan alqoritmlər üzərində işlənilir.
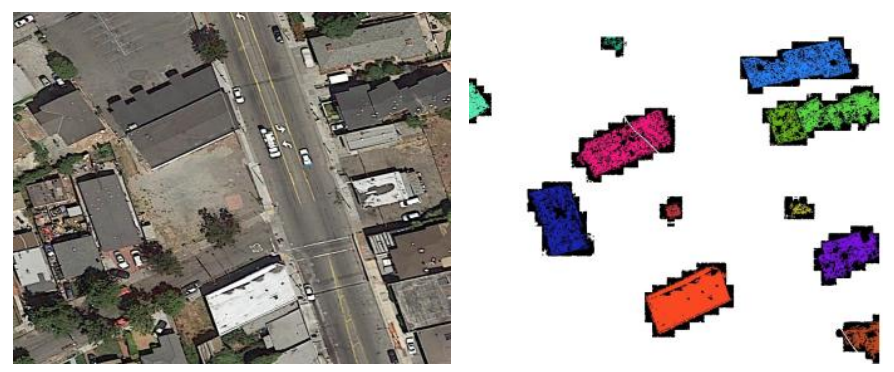

Şəkil 3. Tapılmış binaların konturları

\section{ӘDӘBIYYAT}

[1] H. Mayer, "Automatic object extraction from aerial imagery - A survey focusing on buildings," Computer Vision and Image Understanding, vol. 74, 1999, pp. 138-149

[2] C. "Unsalan and K. L. Boyer. "A system to detect houses and residential street networks in multispectral satellite images," Computer Vision and Image Understanding, vol. 98, 2005, pp. 432-461

[3] S. Levitt and F. Aghdasi, "Fuzzy representation and grouping in building

detection," in International Conference on Image Processing, vol. 3, 2000, pp. 324-327.

[4] Z. Kim and R. Nevatia "Automatic description of complex buildings from multiple images" Computer vision and image understanding, Vol. 96, 2004.

[5] M. Fradkin, H. Maitre and M. Roux "Building detection from multiple aerial images in dense urban areas" Computer vision and image understanding, Vol 82, 2001.

[6] J.Hu, S. You, U. Neumann "Integrating LiDAR, aerial image and ground images for complete urban building modeling" Proceedings of the Third International Symposium on 3D Data Processing, Visualization, and Transmission, 2006.

[7] J. Canny, A Computational Approach To Edge Detection, IEEE Trans. Pattern Analysis and Machine Intelligence, 8(6):679-698, 1986.

[8] R. O. Duda, P. E. Hart, "Use of the Hough Transformation to Detect Lines and Curves in Pictures," Comm. ACM, January, 1972, Vol. 15, pp. $11-15$

[9] https://en.wikipedia.org/wiki/Hue 